\title{
Role of Bcl2I10 in Regulation of Meiotic Cell Cycle in the Mouse Oocyte
}

\author{
Kyung-Ah Lee ${ }^{1}$, Se-Jin Yoon², Eun-Young Kim', Jeehyeon Bae³, \\ Hyun-Seo Lee ${ }^{1}$, Su-Yeon Lee ${ }^{1}$ and Eun-Ah Kim ${ }^{1}$ \\ ${ }^{1}$ Department of Biomedical Science, College of Life Science, CHA University, \\ ${ }^{2}$ Department of Genetics, Stanford University, \\ ${ }^{3}$ Department of Pharmacy, College of Pharmacy, CHA University, \\ 1,3Korea \\ 2USA
}

\section{Introduction}

Bcl2110, also known as Diva or Boo, is a member of the Bcl2 family. This factor is known to have opposing apoptotic functions in various tissues. That is, it can act as either a proapoptotic or an anti-apoptotic factor depending on the cellular milieu (Ke et al., 2001; Lee et al., 2001).

The pro-apoptotic factor Bad is expressed in various tissues including rat ovaries and testes (Kaipia et al., 1997). Bok, anti-apoptotic factor, has been detected in granulosa cells as well as in several reproductive tissues such as the ovaries, testes, and uterus (Hsu et al., 1997). Several anti-apoptotic Bcl2 homologs are expressed in the ovary. Mcl1, Bcl2, Bcl2l1 (Bcl-x), and other $\mathrm{Bcl} 2$ family members have also been detected in ovarian tissues (Hsu et al., 1997; Hsu and Hsueh, 2000; Kim and Tilly, 2004; Tilly et al., 1995). However, the expression patterns of these Bcl2 family members are quite different from those of Bcl2110, which exhibits ovary- and oocyte-specific expression. Murine Bcl2110 was first identified in expressed sequence tag clones from unfertilized, fertilized, and two-cell-stage mouse eggs (Inohara et al., 1998). Expression of this factor is restricted to the ovary and testis in adult mice (Inohara et al., 1998).

\section{Expression of Bcl2I10 in the ovary}

In a previous study, we used the annealing control primer-PCR method to investigate differentially expressed genes in the mouse oocytes. Using this approach, we found that Bcl2l10 was highly expressed in oocytes (Yoon et al., 2005). We confirmed that Bcl2l10 is constantly expressed in oocytes during oocyte maturation and found that its expression disappeared after the four-cell stage (Figure 1).

Since Bcl2l10 is a member of Bcl2 family, we first evaluated the relationship between Bcl2110 expression and apoptosis in the ovary. Surprisingly, Bcl2110 expression did not appear to be 
related to granulosa cell apoptosis in ovarian follicles (Figure 2). Analysis of serial ovarian sections using immunohistochemical labeling for Bcl2110 and TUNEL assay revealed that BCL2L10 expression is oocyte-specific but that this expression is mismatched with the apoptotic death of follicular granulosa cells. Therefore, Bcl2110 may have a function that is not related to the regulation of apoptosis in oocytes.
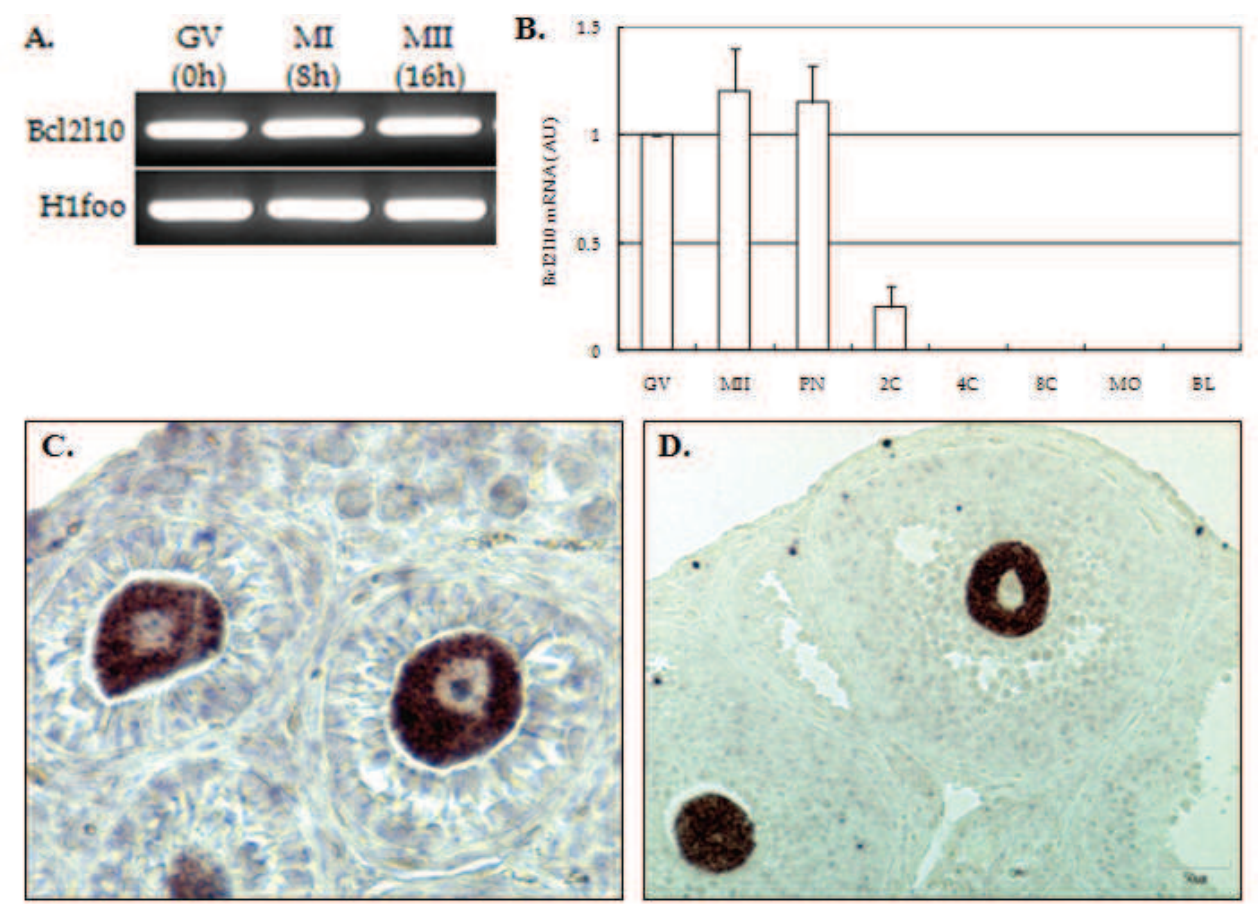

Fig. 1. Expression of Bcl2110 mRNA in oocytes and preimplantational embryos. A) Semiquantitative RT-PCR analysis of $\mathrm{Bcl} 2110$ expression during spontaneous oocyte maturation in vitro. GV, germinal vesicle-stage oocytes; MI, meiosis I oocytes collected after $8 \mathrm{~h}$ of culture; MII, meiosis II-stage oocytes collected after $16 \mathrm{~h}$ of in culture. B) Quantitative real-time RT-PCR of Bcl2110 mRNA in oocytes and embryos. Messenger RNA isolated from oocytes and at various embryonic stages was reverse transcribed. For $\mathrm{PCR}$, the cDNA from a single oocyte or an embryo equivalent served as a template for amplification. The expression level was calculated from the cycle threshold values (CT) based on the fluorescence detected within the geometric region of the semi-log plot, and the mRNA ratio (arbitrary units) was calculated with respect to that of GV oocytes. Experiments were repeated at least three times, and data are expressed as the mean \pm SEM. PN, pronucleus one-cell zygote; 2C, two-cell; 4C, four-cell; 8C, eight-cell; MO, morula; BL, blastocyst-stage embryo. C, D) In situ hybridization of Bcl2110 mRNA. Mouse ovaries of 2-week-old (C) and 4-week-old (D) were used, and we observed the oocytespecific Bcl2110 mRNA expression. Scale bars represent $25 \square \mathrm{m}$ and $50 \square \mathrm{m}$ for $\mathrm{C}$ and D, respectively (C, D cited in Yoon et al., 2006, Korean J Fertil Steril). 

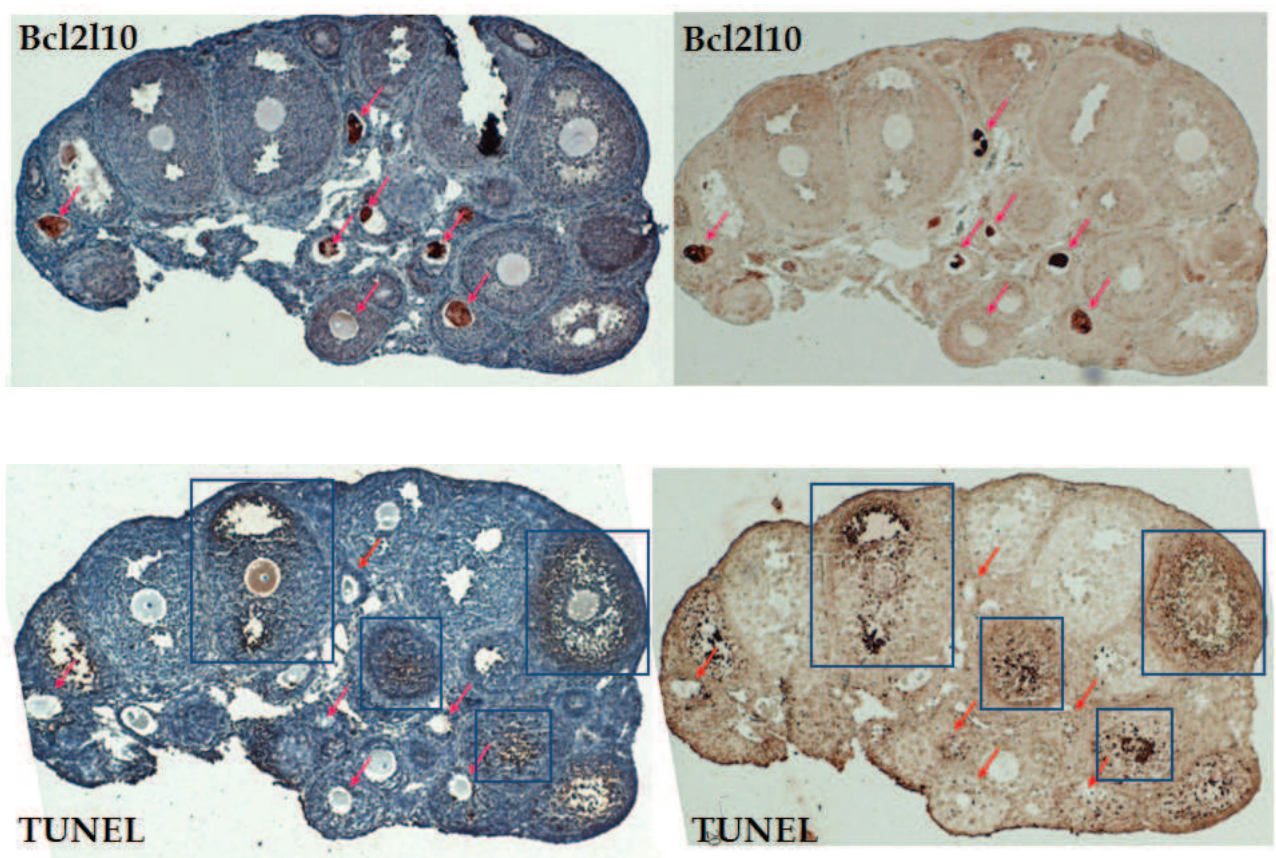

Fig. 2. BCL2L10 immunohistochemical labeling and TUNEL assay in serial sections. Tissue sections were obtained from 4-week mouse ovaries. Arrows indicate peculiar BCL2L10 expression in oocytes of preantral follicles, while boxes indicate apoptotic follicles with TUNEL-positive granulosa cells.

\section{Bcl2/10 binding proteins}

Next, we tried to identify the working partner(s) of Bcl2l10 using immunoprecipitation followed by mass spectrometry (Yoon et al., 2006). We transiently expressed FLAG-Bcl2110 in NIH/3T3 cells and purified Bcl2110-associated proteins (Figure 3). Specifically detected 14 bands were excised in the Coomassie Blue-stained 12\% SDS-PAGE gels and identified using LC/MS/MS analysis. The protein band specific for Diva was identified as Bcl2-like 10 in the size of $21 \mathrm{kDa}$ (Fig. 3, gel slice number 2) suggesting a successful IP analysis using monoclonal anti-FLAG antibody. List of potential Bcl2110-binding partners is summarized in Table 1. Interestingly, many of the identified Bcl2l10-associated proteins are known to be associated with the cytoskeletal system. The identification of actin-related proteins such as actin, a-actinin, gelsolin, myosin, tropomyosin, and tropomodulin 3 as Diva-binding proteins suggests that Diva protein associates with the components of actin filaments. Actin was the most abundant Diva-associated protein as shown in Figure 3 (gel slice number 6). All these proteins, with the exception of actin, are known to bind actin to form, stabilize, and cross-linking the microfilaments. 


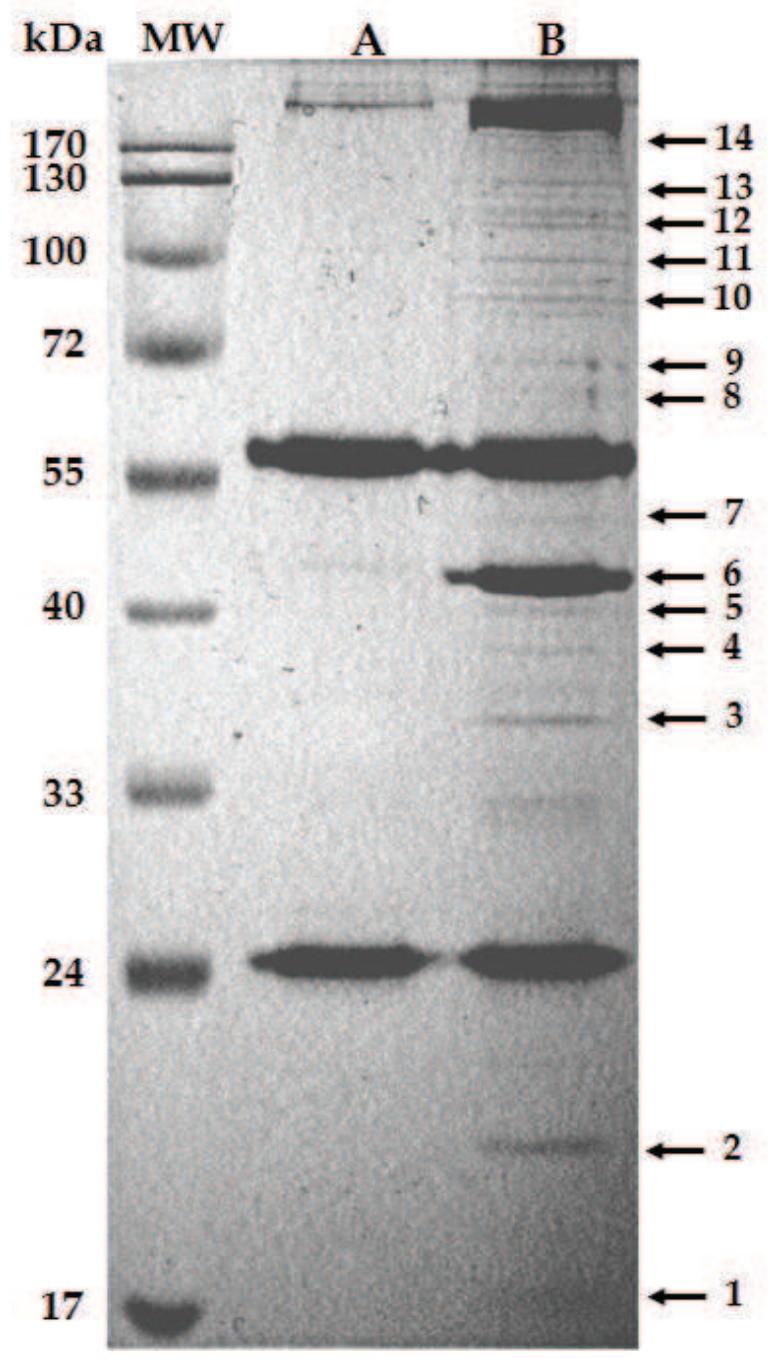

Fig. 3. Identification of BCL2L10-associated proteins. NIH/3T3 cells were transiently transfected for $24 \mathrm{~h}$ with empty vector or FLAG-BCL2L10-expressing vector. Total protein extracts were incubated with anti-FLAG-agarose beads. Anti-FLAG-agarose elutes from an equivalent amount of transfected cells $(500 \mu \mathrm{g})$ were analyzed by $12 \%$ SDS polyacrylamide gel electrophoresis, and proteins were visualized by Coomassie Blue staining. The positions and relative molecular masses in kilodaltons $(\mathrm{kDa})$ of protein size markers are indicated on the left. Protein-containing bands, as indicated by numbers on the right, were excised, and proteins present in gel slices were identified by mass spectrometry. MW, protein size markers; A) NIH/3T3, anti-FLAG-agarose elutes from $\mathrm{NIH} / 3 \mathrm{~T} 3$ cells transfected with pCMV-FLAG empty vector; B) FLAG-BCL2L10, NIH/3T3 cells transfected with pCMV-FLAG-BCL2L10 vector (Yoon et al., 2006). 


\begin{tabular}{lllll}
\hline $\begin{array}{l}\text { Gel slice } \\
\text { number }\end{array}$ & Accession & Score & Description & Unigene \\
\hline 1 & gi_16307437 & 95 & RIKEN cDNA 2900073G15 & 2900073G15Rik \\
2 & gi_30851239 & 69 & Bcl2110 & Bcl2110 \\
3 & gi_1351289 & 69 & Tropomyosin 1 alpha chain (alpha-tropomyosin) & Tpm1 \\
4 & gi_19353393 & 79 & Tpm2 protein; Tropomyosin 2, beta & Tpm2 \\
5 & gi_52139168 & 90 & Tropomodulin 3 & Tmod3 \\
6 & gi_49868 & 109 & Beta-actin (aa 27-375); Actin, beta, cytoplasmic & Actb \\
7 & gi_80478706 & 45 & ARP3 actin-related protein 3 homolog (yeast) & Actr3 \\
8 & gi_194362 & 123 & Igh-4 protein & Igh-4 \\
9 & gi_27369615 & 29 & PIF1 homolo: Expressed sequence AI449441 & AI449441 \\
10 & gi_34871482 & 34 & PREDICTED: similar to Transcription initiation factor & Taf6 \\
11 & gi_90508 & 39 & Gelsolin, cytosolic & Gsn \\
12 & gi_61097906 & 35 & Actinin, alpha 1 & Actn1 \\
13 & gi_47847434 & 42 & mFLJ00150 protein: Centrosomal protein 110 & Cep110 \\
14 & gi_17978023 & 80 & Myosin, heavy polypeptide 9, non-muscle & Myh9 \\
\hline
\end{tabular}

Table 1. Bcl2110-associated proteins identified by immunoprecipitation and mass spectrometry.

Immunoprecipitation/Western blot analysis of ovarian tissue homogenates confirmed the association of actin and tropomyosin with Bcl2110 (Figure 4). These findings suggest that, in the ovary, Bcl2110 plays roles unrelated to apoptosis and instead participates in the regulation of cytoskeletal systems. During meiosis, actin filaments have roles in migration of chromosomes, segregation of homologous chromosomes, development and maintenance of the cortex, formation of polarity, movement of peripheral cortical granules, and extrusion of the first polar body (Sun and Schatten, 2006).

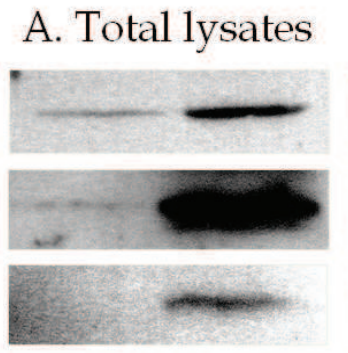

Testis Ovary
B. IP: Diva

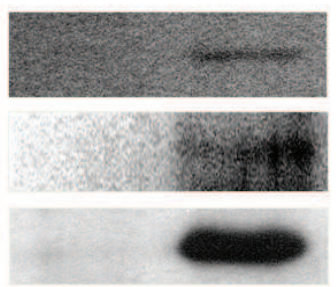

Testis Ovary
WB:

anti-Actin

anti-Tropomyosin

anti-Bcl2110

Fig. 4. Identification of BCL2L10-associated proteins using immunoprecipitation (IP)/Western blot analysis (WB). A) WB analysis. Total protein lysates $(20 \mu \mathrm{g})$ from mouse testes and ovaries were electrophoresed and probed with anti-actin, anti-tropomyosin, or anti-BCL2L10 antibody. Testes lysates served as a negative control for BCL2L10 protein expression. B) IP/WB analysis. Total protein lysates from testes and ovaries (500 $\mu \mathrm{g})$ were subjected to IP using anti-Bcl2l10 antibody. Anti-BCL2L10-agarose elutes were then electrophoresed and probed with anti-actin, anti-tropomyosin, or anti-BCL2L10 antibody to confirm of the association of actin and tropomyosin with BCL2L10 (as cited in Yoon et al., 2006, Korean J Fertil Steril). 
A non-apoptotic function of Bcl2110 has also been demonstrated. Specifically, Bcl2110 plays a role in Huntington-interacting protein 1-related (HIP1R) protein-mediated endocytosis as well as in the regulation of actin machinery in 293T cells. HIP1R regulates clathrin-mediated endocytotic apparatus and actin assembly. An interaction between endogenous BCL2L10 and HIP1R has been shown by immunoprecipitation and Far-Western analysis (Kim et al., 2009).

\section{Function of $\mathrm{Bcl} 2 \mathrm{l} 10$ in oocytes}

We have investigated the role of Bcl2110 not only in the ovary, but also in oocytes. RNA interference (RNAi) was used for this purpose. To determine the role of Bcl2l10 during oocyte maturation, we microinjected in vitro transcribed dsRNA for Bcl2l10 into the cytoplasm of germinal vesicle-stage (GV) oocytes and monitored in vitro oocyte maturation. $\mathrm{Bcl} 2110$ RNAi selectively reduced levels of endogenous Bcl2l10 and resulted in incomplete meiosis that was arrested in meiosis I (MI) (Yoon et al., 2009). MI-arrested oocytes had abnormalities in the spindles and chromosomes. The most prominent changes were the disappearance of spindles and aggregation of chromosomes (Figure 5).
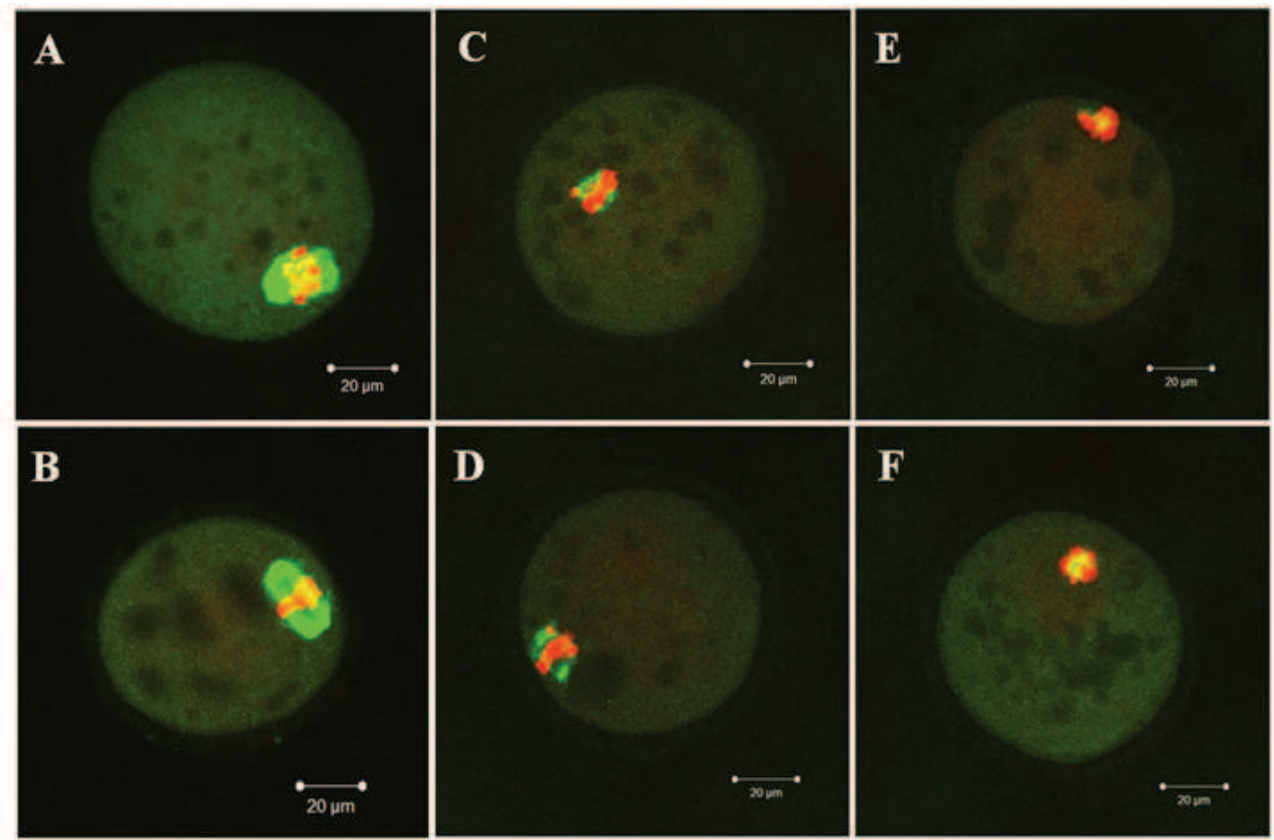

Fig. 5. Bcl2110 RNAi-induced abnormalities in oocytes, as seen by a-tubulin immunofluorescent staining and chromosomal staining. Germinal vesicle oocytes were injected with Bcl2110 dsRNA and cultured for $16 \mathrm{~h}$. Oocytes were then fixed in $4 \%$ paraformaldehyde and stained with an a-tubulin antibody (green). Chromosome material was counterstained with propidium iodide (red). A) Control, uninjected oocyte. B) Bufferinjected control oocyte. C-F) Bcl2110 dsRNA-injected oocytes arrested in meiosis I (as cited in Yoon et al., 2010, From Biol Reprod). Bars represent $20 \mu \mathrm{m}$. 


\section{Genes downstream of Bcl2I10}

After discovering that Bcl2110 RNAi induced changes in spindles and chromosomes, we set out to identify the network of factors acting downstream of Bcl2l10 in oocytes so that we could better understand the regulatory mechanisms underlying meiosis in oocytes. To identify downstream genes, we conducted microarray analysis of Bcl2110 RNAi-induced changes in gene expression in mouse oocytes (Kim et al., 2011).

Due to the small amounts of initial total RNA obtained from the 350 oocytes, we performed an amplifying two-cycle target labeling assay so that we could obtain sufficient amounts of labeled cRNA target for microarray analysis. The labeled cRNA was hybridized to the Affymetrix GeneChip Mouse Genome 4302.0 Array, which covers transcripts and variants from 34,000 well-characterized mouse genes.

Bcl2110 RNAi induced a more than 2-fold up-regulation of 644 genes and down-regulation of 1,166 genes. Notably, the top 20 up-regulated genes included five enzymes (i.e., pyrophosphate synthase, N-methyltransferase, and three kinases). The top 20 downregulated genes were related to cytoskeletal organization (Table 2). These genes encoded proteins such as Tpx2, Cep192, Kir20b, Myo6, and Cd2ap. Tpx2 functions in spindle assembly, Cep192 in microtubule nucleation, Kir20b in microtubule-based movement, Myo6 in physical interactions, and Cd2ap in actin polymerization.

\begin{tabular}{lll}
\hline Genes & Gene title & Fold change \\
\hline Tpx2 & TPX2, microtubule-associated protein homolog & -16.1 \\
Rbm12b & (Xenopus laevis) & -15.3 \\
Ptp4a1 & RNA binding motif protein 12B & -14.6 \\
Ranbp2 & protein tyrosine phosphatase 4a1-like & -10.1 \\
Eea1 & RAN binding protein 2 & -9.3 \\
Arid4a & early endosome antigen 1 & -9.1 \\
Cep192 & AT rich interactive domain 4A (RBP1-like) & -8.2 \\
Kif20b & centrosomal protein 192 & -7.9 \\
Psip1 & kinesin family member 20B & -7.8 \\
Atad2b & PC4 and SFRS1 interacting protein 1 & -7.5 \\
Mki67 & ATPase family, AAA domain containing 2B & -7.4 \\
Nexn & antigen identified by monoclonal antibody Ki 67 & -7.2 \\
Eif4g3 & nexilin & -6.9 \\
Ccnb3 & eukaryotic translation initiation factor 4 gamma, 3 & -6.9 \\
C430048L16Rik & RIKEN cDNA C430048L16 gene & -6.8 \\
Cenpm & centromere protein M & -6.8 \\
Leo1 & Leo1, Paf1/RNA polymerase II complex component & -6.7 \\
Myo6 & myosin VI & -6.6 \\
Tnfaip8 & tumor necrosis factor, alpha-induced protein 8 & -6.6 \\
Cd2ap & CD2-associated protein & -6.5 \\
\hline
\end{tabular}

Table 2. Top 20 genes down-regulated more than 2-fold by Bcl2l10 RNAi.

Tpx2 was found to be down-regulated by 16.1-fold and Cep192 by 8.2-fold. The functions of these proteins are intimately related. Interfering with TPX2 function in HeLa cells causes 
defects in microtubule organization during mitosis, and Tpx2 RNAi produces abnormalities in spindle formation (Gruss et al., 2002). Tpx2, a microtubule-binding protein, and Cep192, a centromere protein, are well-known cofactors of Aurora A kinase. Both proteins act to control the activity and localization of this kinase (Joukov et al., 2011). Eukaryotes have one to three members of the Aurora family of serine-threonine kinases. Aurora A is an important oncogenic kinase that has well-established roles in spindle assembly (Xu et al., 2011). During mitosis, a fraction of Aurora A binds Tpx2, activates the kinase, and targets it to spindle microtubules (Eyers et al., 2003, Kufer et al., 2002, Ozlu et al., 2005, Tsai et al., 2003). Tpx2 controls localization of Aurora A at centrosomes, whereas Cep192 controls its activity in microtubules (Joukov et al., 2010).

Our finding that Bcl2110 RNAi induced concurrent down-regulation of Tpx2 and Cep192 leads us to conclude that Bcl2110 may have important roles in regulating oocyte meiosis through its ability to act as an upstream regulator of Tpx2 and Cep192. Association between $\mathrm{Bcl} 2110$ and Aurora kinase A is an interesting new area that warrants further investigation.

\section{Conclusion}

We have identified Bcl2l10 expression in oocytes and uncovered a role for this factor in regulating meiosis. Our findings point to new non-apoptotic function for this $\mathrm{Bcl} 2$ family member and open a challenging new area of research on $\mathrm{Bcl} 2110$ regulation of meiosis through $\mathrm{Bcl} 2110$ involvement in spindle assembly. We propose that $\mathrm{Bcl} 2110$ is an important regulator of meiotic spindle formation and works closely with Tpx2, Cep192, and Aurora A kinase. The molecular mechanisms underlying meiotic regulation by Bcl2110 and its downstream genes (Tpx2 and Cep192) as well as the relationship between Bcl2110 and Aurora A kinase are currently under careful investigation.

\section{Acknowledgment}

This research was supported by the Basic Science Research Program through the National Research Foundation of Korea (NRF) funded by the Ministry of Education, Science, and Technology (20100022600 and 2009-0068363), by the Priority Research Centers Program through the NRF of Korea funded by the Ministry of Education, Science and Technology (2009-0093821), and by a Korea Research Foundation Grant funded by the Korean Government (KRF-2008-314-E00120).

\section{References}

Eyers PA, Erikson E, Chen LG \& Maller JL. (2003). A novel mechanism for activation of the protein kinase Aurora A. Current Biology, 13, 8, pp.691-697, ISSN 0960-9822

Gruss OJ, Wittmann M, Yokoyama H, Pepperkok R, Kufer T, Sillje H, Karsenti E, Mattaj IW \& Vernos I. (2002). Chromosome-induced microtubule assembly mediated by TPX2 is required for spindle formation in HeLa cells. Nature Cell Biology, 4, 11, pp.871879, ISSN 1465-7392

Hsu SY \& Hsueh AJ. (2000). Tissue-specific Bcl-2 protein partners in apoptosis: an ovarian paradigm. Physiological Reviews, 80, 2, pp.593-614, ISSN 0031-9333 
Hsu SY, Kaipia A, McGee E, Lomeli M \& Hsueh AJ. (1997). Bok is a pro-apoptotic Bcl-2 protein with restricted expression in reproductive tissues and heterodimerizes with selective anti-apoptotic Bcl-2 family members. Proceedings of the National Academy of Sciences of the United States of America, 94, 23, pp.12401-12406, ISSN 0027-8424

Inohara N, Gourley TS, Carrio R, Muniz M, Merino J, Garcia I, Koseki T, Hu Y, Chen S \& Nunez G. (1998). Diva, a Bcl-2 homologue that binds directly to Apaf-1 and induces BH3-independent cell death. Journal of Biological Chemistry, 273, 49, pp.32479-32486, ISSN 0021-9258

Joukov V, De Nicolo A, Rodriguez A \& Walter JC. Livingston DM. (2010). Centrosomal protein of $192 \mathrm{kDa}$ (Cep192) promotes centrosome-driven spindle assembly by engaging in organelle-specific Aurora A activation. Proceedings of the National Academy of Sciences of the United States of America, 107, 49, pp.21022-21027, ISSN 0027-8424

Joukov, V. (2011). Aurora kinases and spindle assembly: Variations on a common theme? Cell Cycle, 10, 6, pp.895-903, ISSN 1538-4101

Kaipia A, Hsu SY \& Hsueh AJ. (1997). Expression and function of a proapoptotic Bcl-2 family member Bcl-XL/Bcl-2-associated death promoter (BAD) in rat ovary. Endocrinology, 138, 12, pp.5497-5504, ISSN 0013-7227

Ke N, Godzik A \& Reed JC. (2001). Bcl-B, a novel bcl-2 family member that differentially binds and regulates bax and bak. Journal of Biological Chemistry, 276, 16, pp.1248112484, 0021-9258

Kim EA, Kim KH, Lee HS, Lee SY, Kim EY, Seo YM, Bae J, Lee KA. (2011). Downstream genes regulated by $\mathrm{Bcl} 2110 \mathrm{RNAi}$ in the mouse oocytes. Development and Reproduction, 15, 1, pp.61-69, ISSN 1226-6752

Kim JD, Won M, Yoon S, Ko JJ, Lee KA, Lee K \& Bae J. (2009). HIP1R interacts with a member of Bcl-2 family, BCL2L10, and induces moderate apoptosis. Cellular Physiology and Biochemistry, 23, 1-3, pp.43-52, ISSN 1015-8987

Kim MR \& Tilly JL. (2004). Current concepts in Bcl-2 family member regulation of female germ cell development and survival. Biochimica and Biophysica Acta, 1644, 2-3, pp.205-210, ISSN 1672-9145

Kufer TA, Sillje HH, Korner R, Gruss OJ, Meraldi P, Nigg EA. (2002). Human TPX2 is required for targeting Aurora-A kinase to the spindle. Journal of Cell Biology, 158, 4, pp.617-623, ISSN 0021-9525

Lee R, Chen J, Matthews CP, McDougall JK \& Neiman PE. (2001). Characterization of nr13related human cell death regulator, boo/diva, in normal and cancer tissues. Biochimica and Biophysica Acta, 1520, 3, pp.187-194, ISSN 1672-9145

Ozlu N, Srayko M, Kinoshita K, Habermann B, O'toole ET, Müller-Reichert T, Schmalz N, Desai A \& Hyman AA. (2005). An essential function of the C. elegans ortholog of TPX2 is to localize activated aurora A kinase to mitotic spindles. Developmental Cell, 9, 2, pp.237-248, ISSN 1534-5807

Sun QY, \& Schatten H. (2006). Regulation of dynamic events by microfilaments during oocyte maturation and fertilization. Reproduction, 131, 2, pp.193-205, ISSN 1470-1626

Tilly JL, Tilly KI, Kenton ML \& Johnson AL. (1995). Expression of members of the Bcl-2 gene family in the immature rat ovary: equine chorionic gonadotropin-mediated inhibition of granulosa cell apoptosis is associated with decreased Bax and 
constitutive Bcl-2 and Bcl-xlong messenger ribonucleic acid levels. Endocrinology, 136, 1, pp.232-241, ISSN 0013-7227

Tsai MY, Wiese C \& Cao K. (2003). A Ran signaling pathway mediated by the mitotic kinase Aurora A in spindle assembly. Nature Cell Biology, 5, 3, pp.242-248, ISSN 1465-7392

Xu X, Wang X, Xiao Z, Li Y \& Wang Y. (2011). Two TPX2-dependent switches control the activity of Aurora A. PLoS ONE, 6, 2, e16757, ISSN 1932-6203

Yoon SJ, Chung HM, Cha KY, Kim NH \& Lee KA. (2005). Identification of differential gene expression in GV vs. MII mouse oocytes by using annealing control primers. Fertility and Sterility, 83, S4, pp.1293-1296, ISSN 0015-0282

Yoon SJ, Kim EY, Kim YS, Lee HS, Kim KH, Bae J, \& Lee KA. (2009). Role of Bcl2-like 10 (Bcl2110) in regulating mouse oocyte maturation. Biology of Reproduction, 81, 3, pp.497-506, ISSN 0006-3363

Yoon SJ, Kim JW, Choi KH, Lee SH \& Lee KA. (2006). Identification of oocyte-specific Divaassociated proteins using mass spectrometry. Korean Journal of Fertility and Sterility, 33, 3, pp.189-198, ISSN 1226-2951 


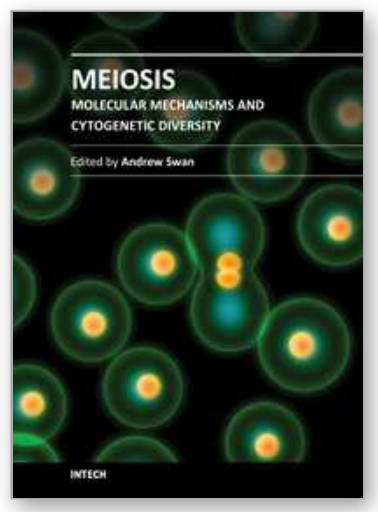

\author{
Meiosis - Molecular Mechanisms and Cytogenetic Diversity \\ Edited by Dr. Andrew Swan
}

ISBN 978-953-51-0118-5

Hard cover, 472 pages

Publisher InTech

Published online 29, February, 2012

Published in print edition February, 2012

Meiosis, the process of forming gametes in preparation for sexual reproduction, has long been a focus of intense study. Meiosis has been studied at the cytological, genetic, molecular and cellular levels. Studies in model systems have revealed common underlying mechanisms while in parallel, studies in diverse organisms have revealed the incredible variation in meiotic mechanisms. This book brings together many of the diverse strands of investigation into this fascinating and challenging field of biology.

\title{
How to reference
}

In order to correctly reference this scholarly work, feel free to copy and paste the following:

Kyung-Ah Lee, Se-Jin Yoon, Eun-Young Kim, Jeehyeon Bae, Hyun-Seo Lee, Su-Yeon Lee and Eun-Ah Kim (2012). Role of Bcl2l10 in Regulation of Meiotic Cell Cycle in the Mouse Oocyte, Meiosis - Molecular Mechanisms and Cytogenetic Diversity, Dr. Andrew Swan (Ed.), ISBN: 978-953-51-0118-5, InTech, Available from: http://www.intechopen.com/books/meiosis-molecular-mechanisms-and-cytogenetic-diversity/role-ofbcl2/10-in-regulation-of-meiotic-cell-cycle-in-the-mouse-oocyte

\section{INTECH}

open science | open minds

\section{InTech Europe}

University Campus STeP Ri

Slavka Krautzeka 83/A

51000 Rijeka, Croatia

Phone: +385 (51) 770447

Fax: +385 (51) 686166

www.intechopen.com

\section{InTech China}

Unit 405, Office Block, Hotel Equatorial Shanghai

No.65, Yan An Road (West), Shanghai, 200040, China

中国上海市延安西路65号上海国际贵都大饭店办公楼 405 单元

Phone: +86-21-62489820

Fax: +86-21-62489821 
(C) 2012 The Author(s). Licensee IntechOpen. This is an open access article distributed under the terms of the Creative Commons Attribution 3.0 License, which permits unrestricted use, distribution, and reproduction in any medium, provided the original work is properly cited. 